\title{
Film Studies at Kent
}

\section{TAMAR JEFFERS McDONALD, University of Kent}

Within the School of Arts at the University of Kent doctoral research in film is located in four main clusters: digital film and animation; cognition; authorship; and history. Despite these broad shared areas of interest individual projects vary enormously in focus, together covering a very wide range of topics, as will be seen.

Within the digital film area, Pete Sillett's work is situated on the borders of animation and cognition, as he investigates how audience empathy and engagement is problematised by animated characters. Frances Kamm's research compares early cinema with contemporary digital developments in order to explore film's relationship to the uncanny in its effect on spectator experience. Caleb Turner examines the spectacle inherent in contemporary superhero bodies, viewing both heroes and the cityscapes in which they operate as representative of discourses around freedom and its limitations.

Within the cognition cluster, Paul Taberham's work explores avant-garde film, considering how such films exploit viewers' perceptual skills and allow them to experience, interpret and perceive in novel and unfamiliar ways. This accent on new perceptions is continued by Luis Rocha Antunes, in his project on the multisensory film experience. He examines this experience from the point of view of several supposedly new "senses", prompting questions on how films might offer a "vestibular" or "proprioceptive" experience. Neil McCartney studies philosophical and neuro-scientific theories of selfhood in the context of films whose narratives contain characters with mutable, unstable identities, looking particularly at how theories in the philosophy of mind can be seen reflected in the work of directors such as David Lynch, Alain Resnais, and Apichatpong Weerasethakul.

This accent on the work of specific directors is matched by other Kent Film students, for whom the auteurist angle is the main focus. Again, it is noticeable how eclectic their researches are beyond this basic point of agreement. Ioanna Papageorgiou works to prove there is more to the works of James Cameron than just high-tech spectacle, huge production values and phenomenal box-office, suggesting that his films also possess an overlooked philosophical depth. Matt Thorpe examines the ethical philosophical possibilities of film, using the Moral Tales of Eric Rohmer as a testing ground. Thorpe claims the films dramatise the expansive direction of an ethical mode of thought in the tension between their protagonists" views of themselves and the view "from outside". Without sacrificing the idea of the ethical, Dominic Topp politicises this "outside" in his work on the films of Jean-Luc Godard and the Dziga Vertov Group. Analysing the interaction between the films' subject matter and their formal and stylistic practices, Topp seeks to examine Godard's work within the context of French politics and film theory of the period. Emre Caglayan uses the work of 
three directors, Béla Tarr, Tsai Ming-Liang and Nuri Bilge Ceylan, as case studies through which to explore the recent "slow" and "contemplative" trend in contemporary art house cinema, defining, examining and situating this trend to trace its beginnings to the modernist aesthetics of the 1960s.

The broad "history" cluster of research covers work on stars, genres, and representation, and is most often concerned with Hollywood cinema, even if only as a counterpoint to the other films and traditions being analysed. While again each project covers very different ground, each is situated within a specific time period and is intent to explore the cultural background of its filmic texts. Sarah Polley's research takes a fresh look at star studies by examining the vehicles, popularity, and "star images" of several onscreen star couples in Hollywood from the 1920 s to the 1950s. Lies Lanckman investigates the relationship between Hollywood cinema and the young women constituting a large part of its audiences from the 1920s to the 1940s, examining how cinema censorship via the Hays Code impacted and altered representations of normative femininity, both within the cinema and in popular film magazines. The research by Stelios Christodoulou concentrates on the representation and cultural currency of Italian-American masculinities in 1970s Hollywood. Considering such films as The Godfather, Rocky and Saturday Night Fever, his project explores how ItalianAmerican ethnicity opens up a space for negotiating social, racial, and gender tensions.

Four further research projects take their starting point from American films and images but do not stop with them. Paul Moran's research examines the post-human world in film and video games, seeking to understand why representations of the space inhabited by artificial beings foreground the aesthetics of decay. In pursuing this research he investigates creation myths, creatures and creators, the gothic and the uncanny, and the aesthetics of posthumanism. The research of Keeley Saunders focuses on the trend in fictional film - post-90s, post-New Queer Cinema - to present female performers in the role of transgendered characters, and explores the gap between existing research on the transgendered subject in film and the alternative representations these films present. Geoff Mann takes the archetypal American genre, the Western, but sees how it fared in England; as by October 1938 Great Britain allegedly accounted for 35\% of the total gross expected from Western films, the American Western seems to have been entrenched as part of the British landscape by this point, while the British market was of considerable importance to American companies producing Westerns. Finally, James Newton examines anarchist cinema, investigating both the thematic and formal qualities that accompany anarchic film texts.

Besides the lively research going on within these traditional doctorates, there is also a strong tradition of Practice as Research within the School, and the first Film PaR PhD has just been awarded. Beyond their studies, research students contribute enormously to the culture of the School of Arts by organising conferences, reading groups and by producing a regular postgrad newsletter; these extra activities contribute to the Film research environment, making it a dynamic and exciting one. We invite students thinking of working in the areas discussed to join us and play a part in this rich environment. 